\title{
Assessing short term erosion-deposition processes of the Brenta River using LiDAR surveys
}

\author{
J. Moretto ${ }^{1}$, F. Delai ${ }^{1}$, E. Rigon ${ }^{1}$, L. Picco ${ }^{1}$, \\ L. $\mathrm{Mao}^{2} \&$ M. A. Lenzi ${ }^{1}$ \\ ${ }^{I}$ Department of Land and Agro-forest Environments, \\ University of Padua, Italy \\ ${ }^{2}$ Department of Ecosystems and Environment, \\ Pontificia Universidad Católica de Chile, Santiago, Chile
}

\begin{abstract}
The extent and amount of erosion and deposition processes experienced by the Brenta river after the flood events of November and December 2010, have been assessed on the basis of DTMs derived from LiDAR surveys made before (2010) and after (2011) these floods. The study, carried out on three sub-reaches of this regulated gravel-bed river took advantage, beside LiDAR elevation data, two relatively novel approaches for channel bathymetry and uncertainty calculation. The first one allowed us to obtain the elevations within the wetted channels while the second method allowed the quantification of uncertainty related to the various phases of the topographic representation process. The erosion-deposition volumetric results derived from the two years DoD differencing models highlighted the impact of the two floods. In all the sub-reaches, erosion processes have dominate and featured a decreasing downstream trend, being the lower reach in a nearly equilibrium condition. The quantitative results of morphological changes have emphasized the evidence that relevant flood events $(\mathrm{RI}>10$ years) in high regulated gravel bed-rivers, encourage erosion rather than deposition patterns.

Keywords: erosion-deposition, floods, LiDAR surveys, gravel-bed rivers, Italy.
\end{abstract}




\section{Introduction}

Italian gravel-bed rivers have suffered, in last centuries, an increasing human pressure which has caused several morphological adjustments in the entire fluvial environment $[1,2]$, producing variations in discharge regime, sediment budget and natural dynamics of riparian vegetation. As a consequence, the river experienced vertical incision/aggradation, and horizontal narrowing/widening channel adjustments $[1,3,6]$. Natural phenomena, represented by large floods, may play a significant role in influencing channel stability and modifications, nevertheless human induced changes are, generally, much greater than those that could be expected from evolutionary dynamics of natural channels.

The Brenta river basin, lying in the North-Eastern Italian Alps, has suffered intense and multiple human impacts, which have altered the catchment and the river channel. After centuries of impacts at the basin scale (mostly phases of deforestation and reforestation), flows have been regulated for hydroelectric power generation and irrigation. Dams were built in many parts of the drainage basin, intercepting sediments from more than $40 \%$ of the drainage area. Moreover, between 1953 and 1985, intense gravel mining was carried out in the main channel. Finally, effective erosion and torrent control works, started in the upper basin in the 1930s [7, 11]. Human interventions have caused, especially during the second half of the $20^{\text {th }}$ century, severe effects, influencing and producing alterations in sediment flux. As a result of these impacts, the average river-bed width reduced from $442 \mathrm{~m}$ at the beginning of the ' 800 to $212 \mathrm{~m}$ in the 2010 , and the channel incision ranged from 2 to $8 \mathrm{~m}$, especially due to the effects of gravel mining that stopped sensibly only during the 1990s. In recent times a new equilibrium and/or widening phases seam to be taking place, (channel widened to $253 \mathrm{~m}$ in 2011) driving the river channel toward a more natural evolution. To better realize the magnitude of different morphological adjustments, the use of precise quantitative approaches is now needed. The development of several representation technologies which derive their DTMs models from precise acquisition data instruments (i.e. LiDAR) has allowed us to reach finer resolutions of large areas in a very short time. Finally, the role of DTMs uncertainty has become more decisive, given that it can strongly affect the volume estimations.

The aim of the contribution is the quantification, taking into account the relative uncertainty, of the short term morphological adjustments of the Brenta river reach between Bassano del Grappa and Carturo. Evidences of channel changes, erosion and deposition patterns are analyzed considering two years, 2010 and 2011, characterized by the occurrence, in November and December 2010, of two consecutive flood events with recurrence interval of about 12 and 16 years, respectively.

\section{Material and methods}

The Brenta river basin is located in the eastern Italian Alps and drains and area of $1567 \mathrm{~km}^{2}$. The study main reach features a length of $19.2 \mathrm{~km}$ and is located 
between Bassano del Grappa and Carturo (Fig. 1a). The average annual precipitation is about $1100 \mathrm{~mm}$, mainly concentrated in spring and autumn seasons. The dominant morphologies of the reach are wandering and braided, the active channel width varies between $300 \mathrm{~m}$ and $800 \mathrm{~m}$, and the average slope is about 0.0036 . Within the study reach, three sub-reaches $1.5 \mathrm{~km}$ long each, have been identified and called using the names of the nearby towns Nove, Friola and Fontaniva (Fig. 1). "Nove" features a single channel structure with a low degree of sinuosity (wandering) and the average width of the active channel is about 300 m. More complex morphological patterns are present in the second sub-reach, "Friola", where the fluvial corridor reaches a width of $500 \mathrm{~m}$ and the vegetation cover results quiet developed. In "Fontaniva", the river divides in several channels, accounting together a width of $800 \mathrm{~m}$, which contribute to form many fluvial islands (braided pattern).

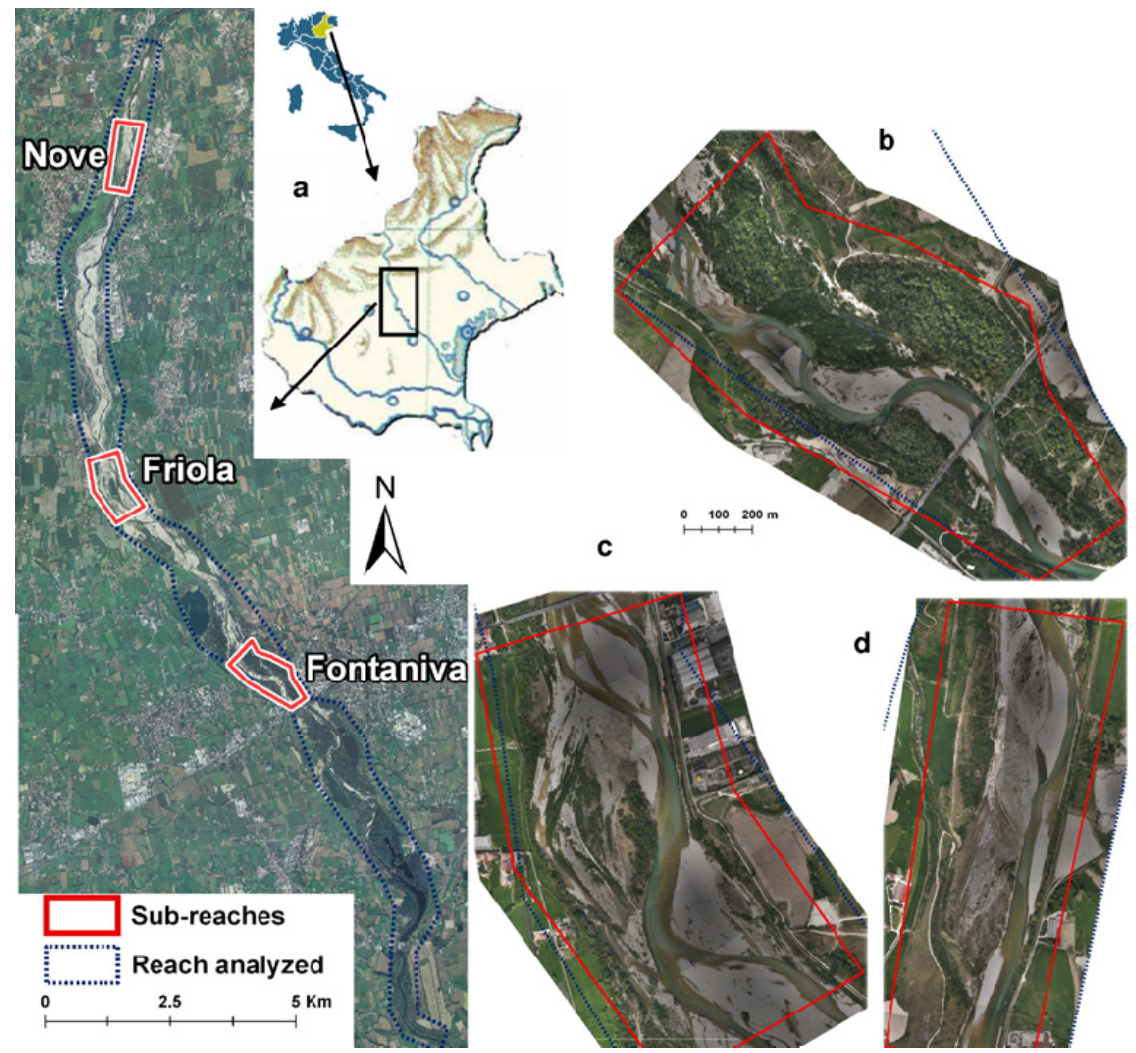

Figure 1: General view of the Brenta reach analyzed (a) and sub-reaches: Fontaniva (b), Friola (c), and Nove (d).

Brenta river basin suffered two severe flood events in the last months of 2010 (Fig. 2). The first one, of a recurrence interval (RI) of about 12 years, was caused 
by a main rainfall of $300 \mathrm{~mm}$ with local maximums over $500 \mathrm{~mm}$ in the period from $31^{\text {st }}$ October to $2^{\text {nd }}$ November 2010. As consequence, a large portion of the basin featured numerous and relevant instability phenomena on hillslopes (landslides, shallow landslides) bank erosion, and flooding outside the banks. Brenta river featured very high hydrometric levels which have risen to the first places of ever registered maximums during the last 30 years. The second flood, $\mathrm{RI}=16$ years, was originated by intensive precipitations, above all on the prealpine and piedmont areas, occurred in Veneto Region between $21^{\text {st }}$ and $26^{\text {th }}$ December 2010. The rainfall exceeded $150 \mathrm{~mm}$, until local maximums reached $300-400 \mathrm{~mm}$. The hydrometric level registered at Barzizza station has been greater for this second event due to the high soil saturation at basin scale and, in particular, to the missed millwork of Corlo reservoir which was already filled by the previous event.

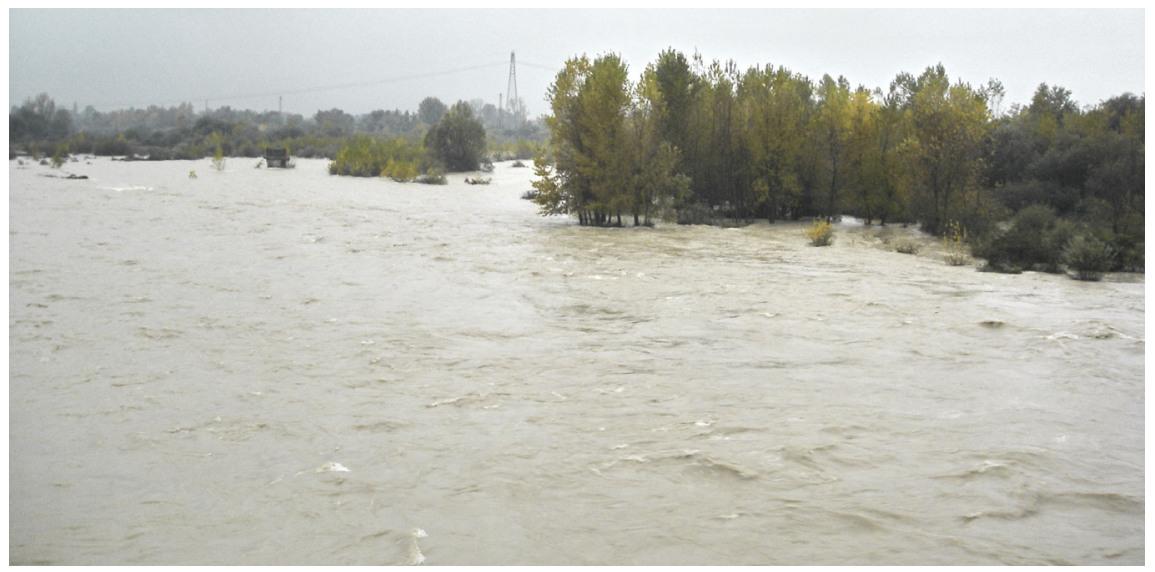

Figure 2: Brenta river by "Friola" during the flood event of November 2010.

The studied sub-reaches were scanned with LiDAR at two different times: August $23^{\text {rd }}$ of 2010 by Blom GCR SpA which used a sensor OPTECH ALTM Gemini; April $24^{\text {th }}$ of 2011 by OGS which used a sensor RIEGL LMS-Q560. The raw LIDAR data were filtered to obtain ground points with the software "TerraScan". To create a more accurate and detailed DTM given that no bathymetric LiDAR surveys account for deep water surfaces, LiDAR data have been integrated with predictive depth - color relationships (color bathymetry). This methodology consists in a calibration of a regression model between water level depth measurements, assessed by Differential Global Positioning System (DGPS), and Red, Green and Blue (RGB) bands values of aerial photos taken contemporary with the LiDAR survey. Through LiDAR points from areas exposed and color bathymetry points of channels of two year we have create the deposition and erosion raster DTM (DoD - differencing models) and the uncertainty calculation through DGPS control points has been assessed. 


\section{Results}

The hydrographs of the two flood events occurred between the subsequent LiDAR flights are shown in figure 3. The November flood reached a maximum discharge of about $800 \mathrm{~m}^{3} / \mathrm{s}$ featuring a slower decrease of water level if compared to the December's, which featured the highest discharge of the last 10 years (peak discharge of $859 \mathrm{~m}^{3} / \mathrm{s}$ ).

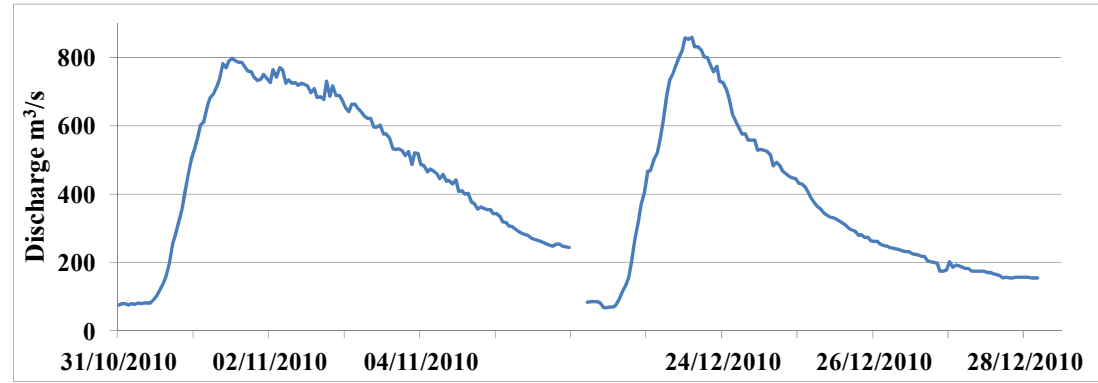

Figure 3: Hydrographs of the flood events of November and December 2010 (Barzizza station).

Digital Terrain Models (DTMs) for each sub-reach for both 2010 and 2011 years were obtained. As to the relationship between the pixel color of wetted areas in the aerial photos and the water depth, a statistical analysis was carried out with the software Minitab. According to the inferential statistics, the variables which are significantly correlated ( $\mathrm{p}$-value $<0.05$ ) to the detrended channel bottom elevations were the red and green bands. The following models have proven to be the best-fitting:

$$
\begin{gathered}
Z_{\text {detrend }}=\mu+(\alpha \cdot R)+(\beta \cdot G) \\
Z_{\text {det_2010 }}=0,041+0,036 R-0,038 \mathrm{G} \\
Z_{\text {det_2011 }}=-0,319+0,023 R-0,019 \mathrm{G}
\end{gathered}
$$

where $Z_{\text {detrend }}$ represents the detrended elevation, $\mu, \alpha$ and $\beta$ are empirical coefficient, and $\mathrm{R}$ and $\mathrm{G}$ the red and green color bands, respectively.

Integrating ground points derived from the ground LiDAR surveys and photo bathymetry, DTMs with $0.5 \mathrm{~m} \times 0.5 \mathrm{~m}$ cell-grid size were obtained. This resolution has been chosen due to the average point density which has been calculated using the raster point density function and was approximately 2.5 point $/ \mathrm{m}^{2}$. Figure 4 shows an example of DTM of Friola sub-reach.

To quantify the uncertainty in the individual DTM surfaces (Tab.1), we have estimated the average uncertainty of part of DTM derived by bathymetry through comparison with ground elevation of wetted areas taken in the field using DGPS. The final uncertainty take into account both uncertainty associated with DGPS and bathymetry measurements. With same method and other DGPS control 


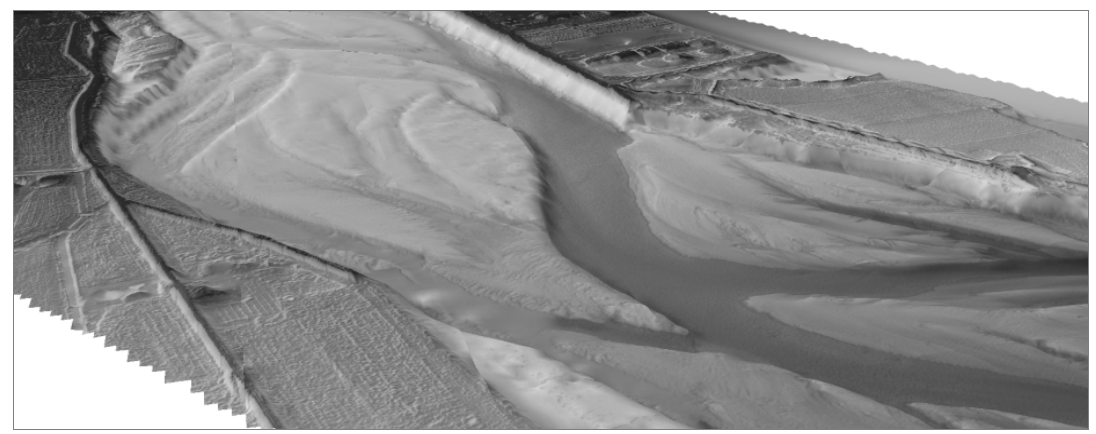

Figure 4: 2011 DTM of Friola sub-reach, with channel bathymetry method.

points we have estimated uncertainty in the remaining part of the DTM derived from LiDAR. The total average uncertainty results equal to $\pm 0.22 \mathrm{~m}$ for 2010 and $\pm 0.14 \mathrm{~m}$ for 2011. Finally, the application of Brasington et al. [12] formula in our DoD, has led to $\pm 0.22 \mathrm{~m}$ of uncertainty for Nove, $\pm 0.29 \mathrm{~m}$ for Friola and $\pm 0.27 \mathrm{~m}$ for Fontaniva. This uncertainty has been distributed over the entire area being examined to quantify the overall error in the calculation of volumes. The estimation of the average errors in volume calculation, according to the Wheaton et al. [13] approach, is about 52\% for Nove, 51\% for Friola and $40 \%$ for Fontaniva reaches.

Table 1: $\quad$ Estimated uncertainty for DTM and for DoD models. S-R: subreach; DTM $_{\mathrm{BTH}}$ : Part of digital elevation model derived by Bathymetry; DTM $_{\mathrm{LD}}$ : Part of digital elevation model derived by light detection and ranging; DGPS: differential global positioning system; $\delta \mathrm{u}_{\mathrm{DoD}}$ : propagated error in raster difference between 2011 and 2010.

\begin{tabular}{|c|c|c|c|c|c|c|c|}
\hline & & \multicolumn{2}{|c|}{ NOVE } & \multicolumn{2}{|c|}{ FRIOLA } & \multicolumn{2}{|c|}{ FONTANIVA } \\
\hline & & 2010 & 2011 & 2010 & 2011 & 2010 & 2011 \\
\hline S-R area & $\left(\mathrm{m}^{2}\right)$ & 556870 & 556870 & 624123 & 624123 & 1225311 & 1225311 \\
\hline Flowing channel area & $\left(\mathrm{m}^{2}\right)$ & 66302 & 113448 & 83339 & 137420 & 67467 & 124899 \\
\hline Flowing channel/S-R area & & 0,12 & 0,20 & 0,13 & 0,22 & 0,06 & 0,10 \\
\hline $\mathrm{N}^{\circ}$ DGPS point for test $\mathrm{DTM}_{\mathrm{BTH}}$ & & 137 & 140 & 234 & 189 & 176 & 146 \\
\hline Average uncertainty DTM $\mathrm{BTH}_{\mathrm{BTH}}+$ DGPS & (m) & $\pm 0,35$ & $\pm 0,20$ & $\pm 0,32$ & $\pm 0,21$ & $\pm 0,24$ & $\pm 0,37$ \\
\hline $\mathrm{N}^{\circ}$ DGPS point for test $\mathrm{DTM}_{\mathrm{LD}}$ & & 78 & 123 & 117 & 155 & 59 & 49 \\
\hline Average uncertainty DTM $\mathrm{LD}_{\mathrm{LD}}+$ DGPS & $(\mathrm{m})$ & $\pm 0,15$ & $\pm 0,11$ & $\pm 0,25$ & $\pm 0,12$ & $\pm 0,23$ & $\pm 0,11$ \\
\hline TOTAL average uncertainty & (m) & $\pm 0,17$ & $\pm 0,13$ & $\pm 0,26$ & $\pm 0,14$ & $\pm 0,23$ & $\pm 0,14$ \\
\hline$\delta \mathrm{uDoD}$ & $(\mathrm{m})$ & \multicolumn{2}{|c|}{ $\pm 0,22$} & \multicolumn{2}{|c|}{ $\pm 0,29$} & \multicolumn{2}{|c|}{ $\pm 0,27$} \\
\hline
\end{tabular}

After creating DTMs and assessing the individual uncertainty related to these representations, we compared the models of the two different years (2010-2011) for each of the three sub-reaches, in order to obtain DoDs and observe the morphological changes occurred in relation to erosion and deposition volumes.

Figure 5 shows the DoD models obtained for "Nove" (a) and "Fontaniva" (b) reaches. 


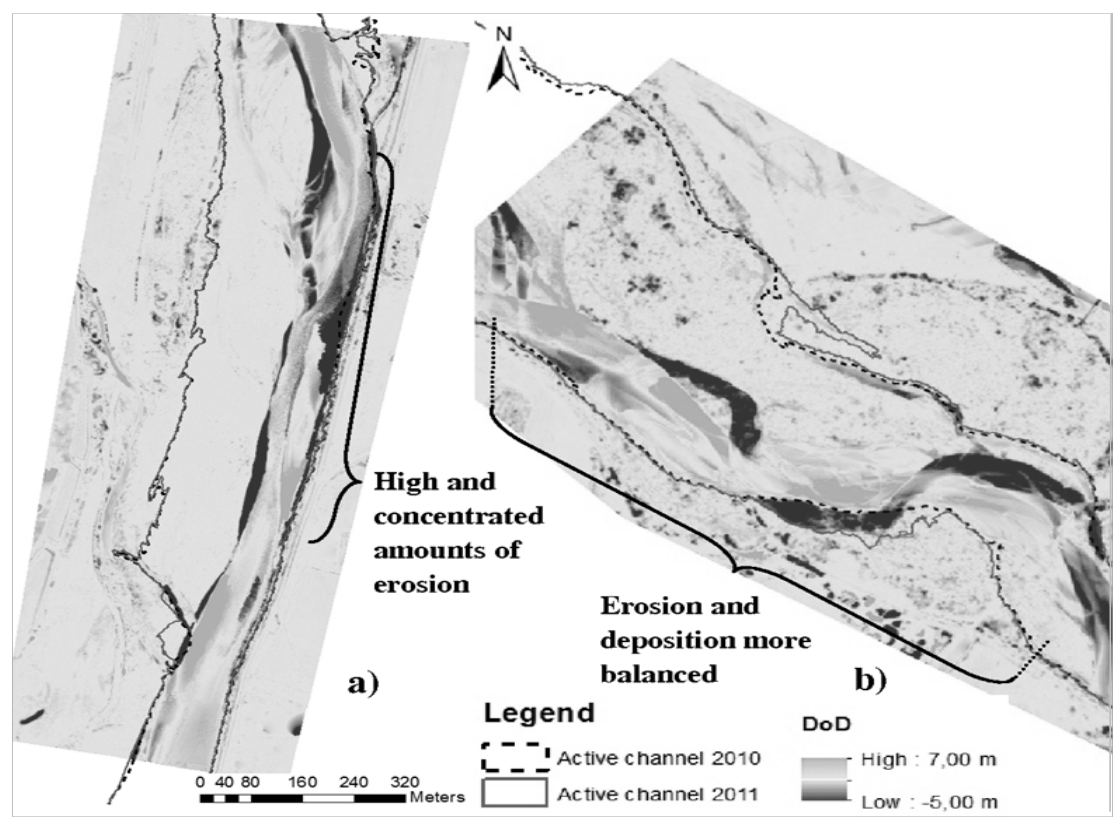

Figure 5: DoD models: variation of erosion and deposition trends of "Nove" and "Fontaniva" sub-reaches.

\section{Discussions}

Looking at a multi-temporal analysis conducted using aerial photographs taken from 1981 to 2011 [6], it appears that narrowing-widening trends of the active channel are marked correlated by the occurrence of flood events. At the reach scale $(19.2 \mathrm{~km})$, an increase in magnitude and frequency of flooding corresponds to an expansion of the active channel, in both absolute and relative terms. Moretto et al. [6] found an interesting correlation $\left(\mathrm{R}^{2}=0.67\right)$ between the variation of the active channel surface and the average values of the maximum annual discharge for the period 1981-2011, even if in recent channel adjustments (short term) is difficult to find a common clear trend if the entire $19.2 \mathrm{~km}$ long reach is considered. Recognizing a general widening of narrowing phase is less obvious due to the complexity and spatially variable patterns of changes at subreach scale. At the reach scale only significant floods with RI $>$ of about 10 years are able to cause important morphological changes [2]. This fact is confirmed also by island reduction processes which take place only with considerable magnitude flood events $[1,2,11,14-17]$. In this sense, November-December 2010 floods caused a decrease in fluvial islands surface, trend that was already present after other significant discharges occurred in the last two decades (1993 and 2002). The relation between severe flood events and island reduction, identified by several authors [2, 6, 17-19], underlines the relevant reduction of 
island surface and marginal vegetation as a consequences of floods in the last two decades, finding a good match with the observations of Bertoldi et al. [14] that confirm a strictly association between island dynamics and major floods (RI $>10-15$ years) in the Tagliamento river.

Despite the fact that natural channel adjustments at reach scale are mainly due to the occurrence of floods events, a fundamental role is played by the individual characteristics at sub-reach level which can strongly influence the change responses in the different parts of the river. The DoD models of the three subreaches have underlined a predominance of erosion processes in relation with the impacts of the flood events of November/December 2010. Linked to this trend, it is also evident that erosion tends to reduce on downstream reaches (Fig. 6).

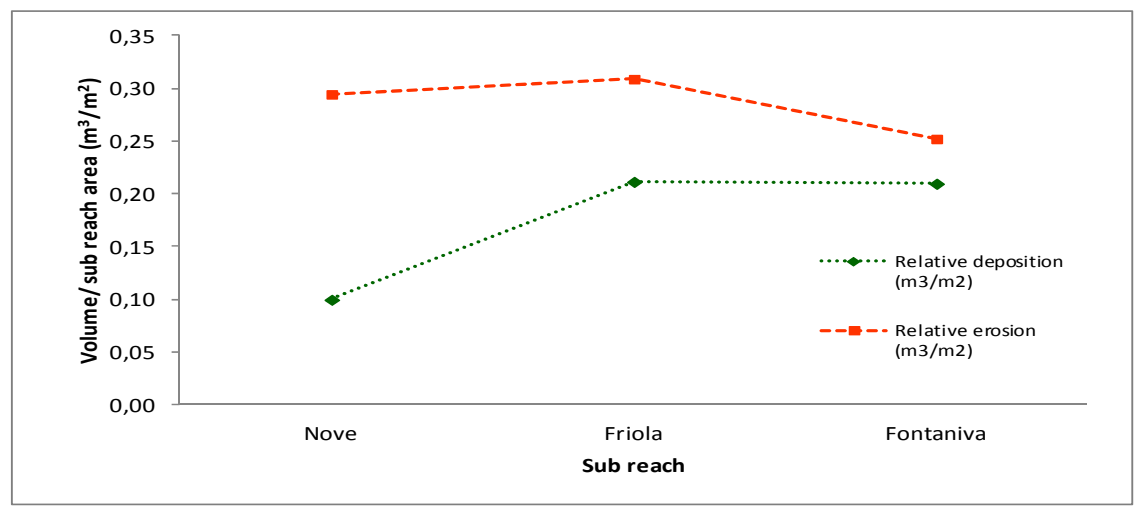

Figure 6: Comparison of relative volumes of erosion and deposition volumes in the different sub-reaches of the Brenta river.

The difference between erosion and deposition amounts is greater (up to three times) and more concentrated in the uppermost reach "Nove" and decreases in downstream reaches. The higher and unevenly distributed erosion processes in the first sub-reach (Fig. 5a) could be due to the higher physical constrains that does not allow the channel to migrate. In fact, human interventions aimed at protecting the nearby areas against dangerous floods (e.g., embankments, groins, and rip raps), could have reduced the active channel width, causing incision trends as partially confirmed by the multi-temporal analysis [6]. The concentrated bank erosion could be enhanced by both the alteration of sediment flux due to the low connectivity with the upstream drainage basin already identified by Surian et al. [1], and by the scarce presence of vegetation growing on the banks. On the contrary in "Fontaniva" sub-reach, the higher amounts of deposition led to a nearly equilibrium condition between erosion and deposition volumes. This could be due to the higher uniformity of the reach and also to the higher degree of freedom that the river channel has to migrate as a result of a general lower human pressure in this section.

....In fact, gravel mining activities were not intensive in this sub-reach in the past, and enough volumes of coarse sediment are available from bank erosion of 
the upper part of the reach. Moreover the presence of vegetation and islands and the "deposition enhancement" caused by an artificially reduced bed slope, could have accounted for its substantial stability and less potential erosion. In this sense, the braiding morphology pattern and the stability trend is conserved in the short and medium term dynamics of this sub-reach.

The reduction of erosion between the different sub-reaches going downstream (Fig. 6) has been confirmed also by the assessment of the relative erosion and deposition amounts and by DoD budget (Tab. 2) with correlated uncertainty.

Table 2: Relative deposition, erosion and DoD budget (deposition volume erosion volume) with uncertainty of active channel of three subreaches.

\begin{tabular}{cccc}
\hline $\begin{array}{c}\text { Sub- } \\
\text { reach }\end{array}$ & $\begin{array}{c}\text { Relative deposition } \\
\left(\mathrm{m}^{3} / \mathrm{m}^{2}\right)\end{array}$ & $\begin{array}{c}\text { Relative erosion } \\
\left(\mathrm{m}^{3} / \mathrm{m}^{2}\right)\end{array}$ & $\begin{array}{c}\text { DoD budget } \\
\left(\mathrm{m}^{3}\right)\end{array}$ \\
\hline Nove & $0,100 \pm 0,05$ & $0,295 \pm 0,16$ & $-54^{\circ} 656 \pm 32 \cdot 603$ \\
Friola & $0,212 \pm 0,11$ & $0,309 \pm 0,15$ & $-49 \cdot 365 \pm 16^{\circ} 475$ \\
Fontaniva & $0,210 \pm 0,09$ & $0,252 \pm 0,09$ & $-18^{\circ} 800 \pm 1^{\circ} 669$ \\
\hline
\end{tabular}

This assessment has shown strong erosion and a "negative" trend in the subreach "Nove". The difference of adjustment responses in respect to the third subreach "Fontaniva", beyond physical aspects of river patterns (minor bed slope and mean velocity), can be strongly related with the alteration of sediment flux. Sediment supply from upstream "Nove" sub-reach is very low due to the presence of dams and torrent control works in the mountain basin. The connectivity with the upstream basin is close to zero for bed-load and coarse sediment input to this sub-reach. Local erosion, in particular bank erosion, is the main source of sediment transported from "Nove" to "Friola" and "Fontaniva" sub-reaches.

In "Friola" sub-reach, the channel has recently undergone a phase of moderate recovery because in-channel mining hasn't longer been carried out and significant bank erosion is carried out in the upstream sub-reach "Nove", supplying coarse material to this sub-reach. In relation with the role of vegetation, in "Nove" the presence of bank vegetation is relative few and that could have contributed to enhance lateral erosion. Evidences of this process can be observed in the DoD model which shows intense red colorations, or rather high values of erosion, along the banks. Different is the situation looking at the "Fontaniva" DoD, where the banks do not feature marked erosion and a possible explanation could be the significant influence of vegetation which is abundant in this sub-reach.

In most cases, erosion appears to affect lateral/bank areas of the river, but in the downstream reaches, such as "Fontaniva" this trend changes and erosion takes place in a more random way. The action of vegetation could have developed and given rise, in this sub-reach, to some areas of incision, as slightly represented in the map (Fig. 5b). A more distributed erosion can also be understood as an higher degree of freedom of the river. Where human pressure is 
not so impacting and space along the fluvial corridor is present, the river is free to expand laterally, originating an horizontal erosive shifting and a general widening of the channel. On the contrary, sub-reaches heavily constrained by human interventions or physical elements, can suffer strong localized erosion processes, giving rise to vertical changes within the channel and representing, in most cases, a lower freedom environment for the river. One more time, the entire framework characterizing a sub-reach is fundamental to explain responses to morphological changes and evaluate future restoration goals.

\section{Final remarks}

The assessment of erosion and deposition sediment volumes diverted by the flooding has been achieved, providing accurate values thanks to the new approach utilized for channel bathymetry which has compensate the not very high precision of LiDAR surveys within water environments (especially with water depth over $40 \mathrm{~cm}$ ) and to the uncertainty estimate which has offered more reliable results. The DoD differencing models have highlighted a predominance of erosion processes in the three sub-reaches of the main river reach of Brenta river, both from visual (maps) and quantitative (volumes rates) point of view.

The erosion-deposition results for the different sub-reaches has emphasized another important trend: erosion patterns decrease going downstream and reach a substantial equilibrium condition in the lower positioned sub-reach, even though deposition still features smaller values. The downstream reduction of erosion was confirmed for the "Fontaniva" sub-reach, inferring as possible explanation, other than the alteration of sediment flux from upstream, the weaker power of the stream linked to the greater presence of vegetation that stabilize the banks. Finally, a significant output, above all to address future restoration actions, has been the evaluation of the sediment motion processes.

.....Looking at the variation of the active channel width and the degree of distribution/spreading out of such patterns, we have been able to observe the actual conditions of the different sub-reaches, understanding where they are more in equilibrium, rather than where they need recovery interventions. In this sense the lower study parts, "Fontaniva" sub-reach, have shown better environmental conditions where the river has been left quiet "free" to expand outside its banks. Further researches are need to improve and reach the closestto-reality as possible results in DTM creation and sediment volume assessment, elements which play a key-role in monitoring and choosing the best restoration solutions for a sustainable development of river environments.

\section{Acknowledgements}

This research was founded by both the CARIPARO "Linking geomorphological processes and vegetation dynamics in gravel-bed rivers" Research Project, and the University of Padua Strategic Research Project PRST08001, "GEORISKS, Geological, morphological and hydrological processes: monitoring, modelling and impact in the North-Eastern Italy”, Research Unit STPD08RWBY-004. 


\section{References}

[1] Surian N., Ziliani L., Comiti F., Lenzi M. A. and L. Mao. Channel adjustments and alteration of sediment fluxes in gravel-bed rivers of northeastern Italy: Potentials and limitations for channel recovery. River Research and Applications 25 (5), 2009, pp. 551-567.

[2] Comiti, F., Da Canal, M., Surian, N., Mao, L., Picco, L. and Lenzi, M. A. Channel adjustments and vegetation cover dynamics in a large gravel bed river over the last 200 years, Geomorphology, 2011, 125, 147-159.

[3] Gurnell, A.M. and Petts, G.E. Island-dominated landscapes of large floodplain rivers, a European perspective, Freshwater Biology, 2002, 47, 581-600.

[4] Gurnell, A.M., Petts, G.E., Hannah, D.M., Smith, B.P.G., Edwards, P.J., Kollmann, J., Ward, J.V. and Tockner, K. Riparian vegetation and island formation along the gravel-bed Fiume Tagliamento, Italy, Earth Surface Processes and Landforms, 2001, 26, 31-62.

[5] Moretto J. Caratterizzazione dei fiumi ghiaiosi naturali ed antropizzati e analisi delle modificazioni più recenti del Fiume Brenta tra Bassano del Grappa e Carturo . MSc Thesis; University of Padova, 2010.

[6] Moretto J., Rigon E. and M. A. Lenzi, 2011. Dinamica evolutiva di medio e breve termine della vegetazione riparia e della morfologia d'alveo del $\mathrm{F}$. Brenta. Convegno di Medio Termine dell'Associazione Italiana di Ingegneria Agraria; Belgirate, 22-24 Settembre 2011, pp. 1-6.

[7] Bathurst J. C., Crosta G. B., Garcìa-Ruiz J. M., Guzzetti F., Lenzi M. A. and Aragues S. R. DAMOCLES: Debris-fall assessment in mountain catchments for local end-users, International Conference on Debris Flow Hazards Mitigation: Mechanics, Prediction and Assessment, Proceedings 2, 2003, pp. 1073-1083.

[8] Conesa Garcìa C. and M. A. Lenzi (eds). Check dams, morphological adjustments and erosion control in torrential streams, Nova Science Publishers Inc., New York, 2010, pp. 339.

[9] Lenzi M. A., D’Agostino V., Gregoretti C., Sonda D. A simplified numerical model for debris-flow hazard assessment: DEFLIMO. International Conference on Debris Flow Hazards Mitigation: Mechanics, Prediction and Assessment, Proceedings 1, 2003, pp. 611-622.

[10] Lenzi M. A. Research developments in debris flow monitoring, modeling and hazard assessment in Italian mountain catchments. WIT Transactions on Ecology and the Environment 90, 2006, pp. 135-145.

[11] Rigon E., Comiti F., Mao L., Lenzi M. A. Relationships among basin area, sediment transport mechanisms and wood storage in mountain basins of the Dolomites (Italian Alps). WIT Transactions on Engineering Sciences 60, 2008, pp. 163-172.

[12] Brasington J, Langham J, Rumsby B. 2003. Methodological sensitivity of morphometric estimates of coarse fluvial sediment transport. Geomorphology 53(3-4): 299-316. DOI: 10.1016/ S0169-555X(02)003203. 
[13] Wheaton J.M., James Brasington, Stephen E. Darby and David A. Sear. "Accounting for uncertainty in DTMs from repeat topographic surveys: improved sediment budgets", 2010. Earth Surface Processes and Landforms 35: pp. 136-156.

[14] Bertoldi, W., Gurnell A., Surian N., Tockner K., Ziliani L., Zolezzi G., 2009. Understanding reference processes: linkages between river flows, sediment dynamics and vegetated landforms along the Tagliamento River, Italy. River Research and Applications 25, 501-516.

[15] Tal, M. and Paola, C. Dynamic single-thread channels maintained by the interaction of flow and vegetation, Geology, 2007, 35, 347-350.

[16] Vitti P. Vegetazione e morfologia fluviale del Piave nel Vallone Bellunese (in Italian). MSc Thesis; University of Padova, 2010, pp. 117.

[17] Vitti P., Picco L., Mao L., Sitzia T., Comiti F., Rigon E. and M. A. Lenzi. Linking riparian forest structure and fluvio-morphological characteristics in a gravel bed river (Piave river-Italian Alps). Poster presented at the International Workshop Advances in River Science, 18-21 April 2011, Swansea, UK.

[18] Delai F. Assessing short-term morphological evolution of gravel-bed rivers using LiDAR surveys. MSc Thesis; University of Padova, 2012, pp. 91.

[19] Picco L., Mao L., Rigon E., Moretto J., Ravazzolo D., Delai F. and M. A. Lenzi, 2012. Riparian forest structure, vegetation cover and floods events in the Piave River (Northeast of Italy). This volume, pp. 11. 